\title{
TABOO LANGUAGE IN MALAY PANAI LANGUAGE OF LABUHAN BILIK DIALECT
}

\author{
Hilman Haidir, Mulyadi \\ University of Sumatera Utara \\ Medan, Indonesia \\ E-mail: hilmanhaidir073@gmail.com
}

Received: 30 January 2019

Accepted: 04 March 2019

\begin{abstract}
This research dealt with the identification of taboo language in Malay Panai Language of Labuhan Bilik Dialect. It is a language spoken by people living in Labuhan Bilik village, Panai Tengah district, Labuhan Batu, Rantau Prapat. The objective of this research was to describe the classification of the taboo words in Malay Panai Language of Labuhan Bilik Dialect (MPLLBD). The research applied was descriptive qualitative approach. The data were collected through observation, recording, and field notes. Then, the data were analyzed by identifying taboo words and categorizing them into the types of taboo words. Thus, each of the taboo words were presented in some examples of utterances in the language. Some words were considered taboo or not depending on the context in which they were used. The finding shows that taboo words in MPLLBD could be either implicit or explicit. In conclusion, there were some classifications of taboo words in the language which were related to the utterances of sex, death, excretion, body function, religion, animals, vague words, and disease.
\end{abstract}

Keywords: Taboo words, Malay Panai language, Labuhan Bili dialect.

\section{Introduction}

Taboo is "abstinence or prohibition" to be done, behaved, and spoken. If abstinence is spoken, that is said to be taboo. Taboo language is a language that is prohibited to speak because it violates moral values, assaults, humiliates, or even judges anybody. (See Trudgill 2000: 18, Wardhaugh, 2006: 349).

Taboo words in each language may have different forms and types. In a language, a word might be identified as taboo but not in another language. The word bujang, in Malay language is not a taboo word because it indicates unmarried person. However, if that word is spoken in Batak region, the word bujang is harsh and means a female genital.

In addition to different regions, it is also determined by the context, such as the situation when the word is spoken. The word pig in a sentence of The coconut seed which I have just planted was eaten by pigs, means "babi" in Malay language and it is not taboo but if it is spoken by the native speaker of MPLLBD to somebody in a mad situation such as Parakalanmu gaya babi kutengok, certainly, it contains very rude meaning. This is clearly taboo, because the sentence means that you act as if you were a pig. Likewise, the word utak which means 'brain' might be a taboo word as in the sentence Lomak botul utak udang en, meaning 'The shrimp's brain is really tasty'. (Usually for broiled shrimp /giant prawns, the brain is quite large. If it is added by the coconut milk, it will be greasy). If compared with such an expression as Sanggup ja ko bacakap bagen, memang dasaR indak baRutak la ko, which 
means 'How dare you? You are insane'; it indicates a person who does not have any heart or is insane.

Even if in any language variation, it may also happen in any dialects to make up taboo words. For example, in MPLLBD, the word bujang includes taboo, whereas in Malay language, it is not taboo because the word bujang means unmarried yet. It so happens because Malay language of Labuhan Bilik Dialect (MPLLBD) has been influenced by other regional languages. One of them is influenced by Mandailing language. For example, in Mandailing language, the word: Anggoitton, imattong meaning 'that is what you are, here you are'. The same meaning in MPLLBD is expressed as goentong and enlantong 'Don't you?, 'Isn't it? Because of the influence of Mandailing language, Mandailing culture also influences Malay culture; thus, the word bujang originally according to Malay language was not taboo but it is taboo in MPLLBD, even though both obviously belong to Malay language.

\section{Literature Review}

Taboo can be defined as the prohibition of a behaviour, thing, person, etc., based on cultural or social norms. It can also be defined as a strong prohibition relating to any area of human activity or social custom that is sacred and forbidden. The prohibition does not allow speakers to say or do the prohibited things because it may cause certain consequences according to the taboo that is violated.

This taboo is found in every society, language, tradition, and habits (Hakim, 2013: 4). Therefore, this taboo can be stated as something that violates the norms and provisions in a particular society, so that it must be avoided. Many experts pay attention to taboo language, such as: Trudgill (2008: 18), Wardhaugh (2006: 239), Jay (1999: 25), McGuire (1973: 4-7), and others. According to Trudgill, taboo refers to something that is prohibited, and he describes taboo as a behavior that is believed to be supernaturally forbidden, or considered immoral, inappropriate; relating to behavior that is prohibited or inhibited in a way that seems irrational.

He further divided taboo words into seven categories; namely, cursing, profanity, blashphemy, obscenity, insult, sexual harassment, and vulgar language. Therefore, Wardhaugh categorizes taboo words regarding taboos related to sex, death, excretion, bodily functions, religion, mother in law, and animal.

On the other hand, unlike Trudgill and Wardhaugh, Jay uses the term curse to define taboo language, and divides it into: (1) swearing; (2) obscenity; (3) Profanity, (4) blashphemy. (5) name calling (6), insults; (7) verbal aggression, (8) taboo speech; (9) ethnicracial insults; (10) vulgarity; and (11) slang (Jay, 1999: 25).

The category of taboo words used to analyze the data is the convergence of the three theories put forward by the experts above. Related to the categories that were not provided in Wardhaugh, it would be complemented by the theories of Trudgill and Timothy. Thus, taboo words are classified into:

\section{Sexuality}

Taboo words which are related to sex may refer to anything in sexuality, or the sex organs of blow job (oral sex) or cunt (vagina), such as in-room sex (bedroom activities), sex in the bathroom (bathroom activities: masturbation, romance with blood relations (mother-inlaw/romance), and sexual abuse. 


\section{Taboo words of death}

The taboo category of death is something scary which is including in this type of taboo language. This is a taboo word because it is considered to have a frightening or scary effect on the person who listens to, so death is one of the taboo words, too. Taboo words related to death may refer to the statements about death including the mention of corpses, graves, names of people who have died and so on.

\section{Excretion}

Excretion is something that is also taboo because it is not in polite way of expression in spoken language to the other persons. The utterance of the word is considered rude or a profanity and can violate ethics. Excretion taboos are taboo words related to human body feces, such as defecation, farting, and so on.

\section{Parts of Human Body}

Taboo words related to human body refer to impolite words in spoken language to express feelings of being angry/mad, mocking, and insulting by teasing parts of one's body such as "dick, pussy, tits, etc".

\section{Religion}

Taboo words related to religion are nonsensical as insulting in the name of God or mocking the Holy book.

\section{Animal}

It is a taboo word to insult someone by mentioning names of animals or pointing out their appearance and behavior, mental abilities, character or social relations. The use of taboo words in this way will be condemned by the society because of comparing human beings with animals such as by using the words pig, dog, monkey, etc.

\section{Curse}

Timothy defines that cursing or "curse" as an attempt "to harm others through the use of certain words or phrases" (Jay, 1996: 8). In Malay community of Labuhan Bilik, this curse is noted for the existence of the Legend of Sikantan, which is a folk tale about a rebellious child cursed by the mother. The taboo curse also includes condemnation. Curse means the use of harsh words for cursing, so that other people might get hurt, as an expression of upsetness, anger, or even madness.

\section{Name Calling}

Taboo words in this category are mentioning the names of parents (father and mother), although it is not with the intention of mocking or insulting. In addition, this category is also about "insults", mention of names and ethnic insults and such words are spoken with the aims of hurting, humiliating, and blurring. Many insults and humilitations are related to lack of respect for others by the speakers (Jay, 2009).

The categories of taboo words certainly have different functions. They are (1) Creating Attention which is to take someone's attention; (2) Discrediting Function is to redirect someone; (3) Provocating, to issue in the name of provocation; (4) Identification Function is to show self-identity; and (5) Providing Catharsis Expression Function is to release frustration/pain (McGuire: 1973: 4-7). 


\section{Research Method}

The research was conducted by using a qualitative approach, and the method was descriptive. The data analysis was carried out based on a qualitative approach. Moleong (2012: 11) states that in the descriptive method, the data would be in the form of facts, figures, and but not in numbers so that the research report contains citations to provide an overview of the research. The data were taken from the case study of taboo words in Malay Panai Language of Labuhan Bilik Dialect. The sources of the data were the speakers of Malay Panai Language.

In collecting the data, Purposive Sampling was used, where the technique was to determine the samples in certain considerations. The number of samples (informants) were five native speakers of Malay Panai Language with the total words about 100 taboo words. The informants came from the selected social community and well-known for being honest, sincere, matured, and not disable in speaking (mute).

In collecting the data, the researcher used field notes, interviews, and recording techniques. The whole data taken were the oral form with interview guides and tape recorders.

\section{Results and Discussion}

Based on the data analysis, the taboo words of MPLLBD can be categorized into two major parts, namely (a) Implicit Taboo words, which remain taboo without depending on the context, and (b) Explicit Taboo words, which are based on contextual meaning:

\subsection{Implicit Taboo Words}

Implicit taboo words mean some words whose meanings remain taboo without depending on the context. In any situation, some of the following words remain taboo.

Table 1:

Examples of Implicit Taboo Words

\begin{tabular}{|c|c|c|}
\hline No & MPLBD Words & Glossary \\
\hline 1 & Nentot & Fucking/Sleeping with \\
\hline 2. & MaRancap & Masturbation \\
\hline 3. & Pangkah punggong & Sodomy \\
\hline 4. & Cipo' & Kissing (on lips) \\
\hline 5. & Sundal & Flirting person \\
\hline 6. & Gayit & Flirting person \\
\hline 7. & Lonte & Bitch/Slut \\
\hline 8 & Pukima' & Fuck you!/Son of a bitch! \\
\hline 9 & Cepet & Pussy/Vagina \\
\hline 10 & Bincil & PussyVagina \\
\hline 11 & Kontol & Dick/Penis \\
\hline 12 & Pilat & Dick Penis \\
\hline 13 & Tete' & Breast/Tits/boobs \\
\hline 14 & Pantat & Ass/butt \\
\hline 15. & Takangkang & Straddling \\
\hline 16. & Mampus & Hell you! \\
\hline 17. & Mens & Menses \\
\hline 18. & Haid & Menstruation \\
\hline 19 & Mani & Cum/sperms \\
\hline
\end{tabular}




\begin{tabular}{|c|c|c|}
\hline 20 & KuRap & Ringworm/Scabies \\
\hline 21 & BoRo' & Ulcer/boils \\
\hline 22 & Sawan & Epilepsy/Convulsion \\
\hline 23 & Untut & Elephantiasis \\
\hline 24 & Tungke' & Ear pus \\
\hline
\end{tabular}

NB: $R=$ uvular

\subsection{Explicit Taboo Words}

Explicit taboo words are some taboo words which depend on the context. On one hand, those might mean taboo contextually, but on another context, the word might mean as neutral (not taboo). See the following table.

Tabel 2:

Examples of Explicit Taboo Words

\begin{tabular}{|c|l|l|}
\hline No. & \multicolumn{1}{|c|}{$\begin{array}{c}\text { Explicit Taboo } \\
\text { Words }\end{array}$} \\
\hline 1. & Mangocok & Masturbating \\
\hline 2. & Gatal & Itchy \\
\hline 3. & Janda & Widow \\
\hline 4. & Bunting & Pregnant \\
\hline 5. & Mangintip & Peep \\
\hline 6. & Kamaluan & Genitals/Sexual Organs \\
\hline 7. & Muncong & Shut up! \\
\hline 8. & Punggong & Back \\
\hline 9. & baRutak & Brained \\
\hline 10. & Tengkak & Limp/lame \\
\hline 11. & Pokak & Deaf \\
\hline 12. & Kapala & Head \\
\hline 13. & Mata & Eyes \\
\hline 14. & Buta & Blind/eyeless/sightless \\
\hline 15. & Babi & Pig/swine \\
\hline 16. & Lombu & Ox \\
\hline 17. & HaRimo & Tiger \\
\hline 18. & UlaR & Snake \\
\hline 19. & Buaya & Crocodile/Alligator \\
\hline 20. & Anjing & Dog \\
\hline 21. & Binatang & Monkey/ape \\
\hline 22. & Monyet & Maggot \\
\hline 23. & Ulat & \\
\hline
\end{tabular}

Consider the following examples:

1. "Ia mangocok di kamaR mandi". ( $\mathrm{T}=$ masturbation)

"Hati-hati mangocok toloR en, jangan sampek tumpah". (NT = mix/ whisk eggs)

2. "Gatal botul paRampuan en". (T = flirty)

"Tangan kananku gatal, mungkin ondak dapat duitika". ( NT = itchy,)

3. "Dasar janda, tukang goda lakik uRang". (T= negative meaning, woman who loves teasing/flirting a husband of other women).

"Jika suaminya meninggal, maka setatus istrinya jadi janda". (NT = widow) 
4. "Ia bunting di luaR nikah". ( $\mathrm{T}=$ Pregnant before married) "Kambingku sudah bunting". (NT = pregnant to indicate animals).

5. "la tatangkap basah mangintip malam". Jumat ( $T$ = peeping at a husband and a wife to have sex/ peeping at a man sleeps with a woman on Friday Night while having masturbation). "Sudah tiga malam kayi mangintip pancuRi en". ( NT=We are peeking at the thief).

6. "Sangkinkan kotatnya cilananyen, Nampak kamaluannya mambokang". (T= Vagina) "KaRana ia indak datang samalam, ia kamaluan manengokku". ( NT =Ashamed)

7. "Diamlah muncongmen". ( $\mathrm{T}$ = Stop talking/ Talk to my hand) "Muncong mariam en mangaRah kasika".( NT= mouth of a cannon)

8. "Punggong la di ko"( $\mathrm{T}=$ Ass/Butt) "Sakit punggongku" ( T=Back/backache )

9. "Sanggup jako bacakap bagen, memang dasaR indak baRutaklah ko". ( $T=$ How dare you say like that? You are insane!) "Lomak botul utak udang en". (NT= Usually for broiled shrimp /giant prawns, the brain is quite large. If it is added by the coconut milk, it will be greasy)

10. "Kamana si tengkak tain". ( $\mathrm{T}=$ limp/hobble in terms of humiliating, mocking) "Mangapa ko bajalan tatengkak-tengkak".( NT= limp in terms of astonishing).

11. "Nang pokak lako". ( $\mathrm{T}=$ deaf; in terms of humiliating, blurring) "Pokak talingaku mandongaR suaRa kibot en".( NT = deaf, disability in hearing)

12. "Kapala atok men".( $\mathrm{T}=$ head in terms of mad situation and humiliating). "Kapalaku poning".( NT =head, parts of body)

13. "Kamana mata men kau buat". ( T= eyes; in resentful) "Mataku sakit". ( NT = eyes/sight)

14. "Bagen bosaR jalan en, kok tasipakmulah kakiku ika". "Nam buta ja mata men kuak". ( $\mathrm{T}=\mathrm{blind} / \mathrm{in}$ terms of mad situation, resentful) "Akibat kacalakaan en, buta matanya".(NT= sightless, cannot see anything more)

15. "Gaya babi kutengok paRakalanmu en". ( T= pig/n terms of cursing, abusing, and calling down someone), "Bibit kelapa itu dimakan babi".( NT = to indicate a pig as an animal)

16. "Asek makan sajo koRjamu,paslahko kayak lombu". ( $\mathrm{T}=\mathrm{Ox} / \mathrm{rude}$, in terms of mocking/taunting someone) "PiaRaan lombunya makin bakombang". (NT= ox as cattle)

17. "Aku indak pala takut sama haRimo di sika".( prohibitedly mentioned in the middle of woods ( $T=$ tiger)

"Di hutan en masih ada haRimo". (NT*if it is not mentioned in middle of woods= tiger)

18. "Janganlah ada ulaR di sika".( prohibitedly mentioned in the middle of woods, $\mathrm{T}=$ snake)

"UlaR en bosaR botul". (NT = snake *if it is not said in the middle of woods)

19. "Ati-ati, ia en takonal buaya". ( $T=$ a playboy; in terms of mocking a man just because that man loves to cheat women).

"Di sunge en ada buaya". (NT = an alligator/a crocodile)

20. "KoRjamu mangganggu uRang sajo, manyalak kayak anjing".( $\mathrm{T}=\mathrm{a} \mathrm{dog} / \mathrm{in}$ terms of being mad and humiliating someone)

"Anjingnya mati"( NT= a dog as an animal/pet) 
21. "Kayak binatang kutengok paRakalanmu". ( $\mathrm{T}=$ beast/in terms of being mad to someone).

"Ada binatang kocik masok kamatanya" ( NT= animal, in terms of saying the real objects).

22. "DasaR monyet ndak tahu bataRima kaseh". ( $\mathrm{T}=$ to compare a person with a monkey because his misbehavior).

"Habis pisang en dimakan monyet en".( NT= to point out a monkey)

23. "BaRulat kaki nyen". ( $\mathrm{T}=$ to curse someone, worm-eaten/mad/hate)

"Mangga en banyak yang busok, baRulat".(NT= worm-eaten for a thing such as rotten for some fruits, etc.)

24. "Indak jua ia nikah, bakapanglah".( $\mathrm{T}=$ to humiliate by comparing with an animal/metaphor)

"Terlalu lama kayu en taRondam, jadi bakapang jadinya". ( NT= to state that a thing is eaten by animals/mold).

NB: ${ }^{*} T=T a b o o$

${ }^{*} N T=$ Not Taboo

4.3 Classification of Taboo Words in MPLLBD :

\subsubsection{Taboo Words Related to Sex}

Table 3:

Taboo Words in MPLLBD Represent to Sex

\begin{tabular}{|c|l|l|}
\hline No & \multicolumn{1}{|c|}{ MPLLD } & \multicolumn{1}{c|}{ Glossary } \\
\hline 1. & Nentot & Fucking/Sleeping with \\
\hline 2. & maRancap & Masturbation \\
\hline 3. & mangoco? & Masturbation \\
\hline 4. & Pangkah Punggong & Sodomy \\
\hline 5. & cipo? & Kissing \\
\hline 6 & Sundal & Flirting person \\
\hline 7. & Gayit & Flirting person \\
\hline 8. & Gatal & Flirtatious \\
\hline 9. & Lonte & Bitch/Slut \\
\hline 10. & Janda & Widow \\
\hline 11. & Buntin & Pregnant/impregnate \\
\hline
\end{tabular}

${ }^{*}$ ngentot/yentot/

\section{1. "nentot"}

It is one of taboo words related to sex in MPLLBD which is taboo in a spoken language to publics. The word "nentot" refers to sexual activity which is an action of sleeping with or fucking somebody. If, the word is spoken to publics, certainly it is considered as impolite word, immoral, or rude. In addition, mentioning that word, has manners in speech act and it violates norms and humiliates others."

\section{Marancap/maRancap}

Likewise, if you see a young man who looks weak, unenergized, people might mock ridiculously by saying "maRancap saja koRjamu, apa indak lomas ".Kata"maRancap dan mangocok". It contains the same and impolite expression such as having masturbation.

\section{Mangoco}

It also has the synonym of the word "marancap" which indicates a sexual activity done by a man as, "mangoco saja disiten" 


\section{Pangkah punggong}

Another taboo word related to sex in MPLLBD is the word "pangkah punggong". This word also implies a taboo meaning for doing sodomy.

\section{Cipo}

Similarly, the word "cipok" if it is spoken to publics, then people might think the speakers are rude, impolite because that word implies kissing one and another.

\section{Sundal}

The word "Sundal in MPLLBD is interpreted as a woman who is seductive; the language definitely leads to sex, with a sexy appearance and wearing sexy clothes.

\section{Gayit}

It is similar with the meaning of the word "sundal". Sometimes, the speakers of MPLLBD use this word without any comparison of using the word "sundal".

\section{Gatal}

This kind of word is not really taboo if the speaker of MPLLBD uses it in any condition. Eventhough it has the same meaning with "sundal and gayit", the context is not actually often used by any other speakers in Indonesian language such as "Lihat, gatal kali tanganmu sampai jatuh pot bunga ini".

\section{Lonte}

Thus, the word "Ionte" is used for calling out a woman who acts as a bitch, a whore, or a slut.There are some different usage and in the meaning of saying the word "sundal and lonte". "Sundal", is viewed from the utterance by tempting, tending to use sex words/ sentences, but not to prostituting herself. While the "Ionte" is to point the action of a women who likes to do prostitution.

\section{Janda}

There is a worse perception of using this word of "janda" in MPLLBD. It means as a widow bears a negative meaning by doing something flirtatious, as glancing at, and teasing other people's husbands. Therefore, this word is interpreted as taboo in MPLLBD.

\section{Bunting}

If the word "bunting" is spoken to publics, it may indicate the terms of a woman who is pregnant before married.

Example :"Bunting sajokoRjanya".( to say a woman who likes giving a childbirth).

\subsubsection{Taboo Words Related to Death}

Table 4:

Taboo Words in MPLLBD Represent to Death

\begin{tabular}{|c|l|l|}
\hline No. & \multicolumn{1}{|c|}{ MPLLBD } & \multicolumn{1}{c|}{ Glossary } \\
\hline 1. & Sipulan & $\begin{array}{l}\text { Calling down someone's name who is } \\
\text { already dead. }\end{array}$ \\
\hline 2. & Sakarat & Dying \\
\hline 3. & Mampus & Dead/deadly/ Damn! \\
\hline 4. & Mati & Dead/passed away \\
\hline 5. & Bangke & Corpse/carcass \\
\hline 6. & ManyingKot & Suicide in hanging one self/ kill himself \\
\hline 7. & Manguyak kain kafan & Tear shroud \\
\hline 8. & Taloqin & *Talqin \\
\hline 9. & kaRonda & Coffin/casket \\
\hline
\end{tabular}




\begin{tabular}{|l|l|l|}
\hline 10. & aRwah & Ghost/Spirit \\
\hline 11. & malekalmaut & The (grim) reaper \\
\hline
\end{tabular}

NB:*Talqin is an Arabic word recited for the corpse.

Consider these following examples:

1. "Sipulan dolu" (by mentioning the name of the deceased person). This is taboo, by telling his disgraceness. Even if it is obliged to mention, the name of the deceased will be the late one.

2. "Sakarat" ( Sakaratul Maut) is interpreted as the health condition of a person dying, seriously injured, or in emergency. However, we might not say "Ia sedang dalam sakaratul maut "instead of "He is in a critical period".

3. "Mampus" is figuratively interpreted as the expression of someone's death roughly, by showing annoyance or anger. The word of "mampus" is extremely a taboo such as "Mampusko di siten". ( Damned, you!) in a very rude expression. It means that this word remains taboo without considering or paying attention to the context.

4. Unlike the word "mampus", the word "mati" functions as either a taboo word or not.

Examples :

"Mati ko di siten". (Bloody hell, Hell you!). This word may refer to a taboo word, somehow Ayam itu mati semua. ( The chickens are all dead, *not taboo)

The word "bangke" (data 5,1). It also means as the word "cadaver/corpse" to represent the word "dead".

Compare these following sentences:

5. Bangke (NT = The chicken carcass has been thrown away).

Bangke ( $T$ = The killer carcass has been found). ( "bangke") in this case it is to point out a corpse for human body by showing the expression of hate, madness, or annoyance to curse someone such as initializing a human to an animal.

$N B: T=$ taboo; $N T=$ Not $T a b o o$.

6. "Manyingkot" = hanged oneself/suicide. "DaRipada hidup bagiko, lobih eloklahko manyingkot".

You would better hang yourself rather than live such as this.

7. "SuaRamen kudongaR gaya manguyak kain kafan". (Your voice sounds like tearing shroud). Tearing shroud is taboo, sounding rude to hear.

8. "Taloqin" is a recitation to bury a deceased person. Obviously, this one is rarely recited but it only happens during the funeral and leaving the happening. Usually, *ustadz is the one who recites Taloqin.

NB: Ustadz is an honorific title for a man used in Moslems

9. "KaRonda" is a place to carry corpses to the cemetery, and is usually put in a mosque / prayer room / madrasah at the back of mosque (in the warehouse). "Awasko, datang kaRonda bapakmu". It means you would be better if your dad's ghost is coming after you. This utterance is rarely used, only for the deceased ones.

10. "Arwah" is a term of a spirit for people who passed away. Arwah si polan nya uRang en bagantayangan.(Polan's ghost is wandering). Example, "Sumbayangla kamu, ika malam Jumaat, arwah bapakko datang" which has the same meaning with the example of number 9, your dad's ghost is coming after you. To say impolitely, the word "ghost" is used. While in polite way, the word "spirit" represents it. 


\section{Malekal maut}

"Jangan sampek malekal maut mangincop nyawamu". (Do not let the grim reaper take your life away.

\subsubsection{Taboo Words for Human Excretion}

Excretion means human waste which is paid as taboo because it is rude and impolite in spoken language. The term of this word is considered inappropriate for others and definitely violates the norms of human civility.

Table 5:

Taboo Words in MPLLBD Representing Human Excretion

\begin{tabular}{|c|l|l|}
\hline No. & \multicolumn{1}{|c|}{ MPLLBD } & \multicolumn{1}{c|}{ Glossary } \\
\hline 1. & beRak & bullshit/feces/excretiom \\
\hline 2. & ciRit & Feces \\
\hline 3. & Kincit & Accidentally defecated in a tiny bit \\
\hline 4. & Mens & Menses/period \\
\hline 5. & Haid & Menstruate/menstruation \\
\hline 6. & Mani & Cum/sperm \\
\hline 7. & kuRap & Ringworm/scabies/scald \\
\hline 8 & Sawan & Epilepsy \\
\hline 9 & Untut & Elephantiasis \\
\hline 10. & Tungkek & Ear pus \\
\hline
\end{tabular}

1. "Berakla di ko". (Bullshit!) this expression is used to command someone in mad situation.

2. "CiRitmulah". This word is used to show someone who speaks to another in annoying expression. In that case, the man does not really like everything said or done by his partner in the conversation. Simply, it means "Bullshit!".

3. "Takincit ko kutengok". It indicates to humiliate someone in having excretion or accidentally defecation in a tiny bit in his underwear. It is taboo to say and seems to be dirty.

4. "Ia sudah mens". When someone says this word, it has a sound of taboo rather than saying the girl has got menstruation (in period). In MPLLBD, the speaker does not actually have the substitution word instead of saying "mens". In MPLLBD, the word "mens" is not taboo yet for the ordinary people it is.

5. "la indak layi dapat haids". (Menopause). This word has the same meaning with "mens", but haids is not very taboo when another speaker hears it rather than using "mens".

6. "Ia diejek uRang kuRang mani". The utterance may refer to someone who is being humiliated by another that he has a bit of "sperm" or infertility.

7. "Indak ada uRang yang mau dokat dengannya, kaRana ia bakuRap". In a conversation, this sentence could give some perspectives that nobody wants to make friends with him because he has got ringworms).

8. "Ati-ati, jangan dokat-dokat dengannya, ia punya panyakit sawan". It also humiliates and mocks someone not to stay closer with anybody because he has got epilepsy.

9. "Ati-ati, jangan dokat-dokat dengannya, manjangkit kang untutnyen". This utterance has also the similar meaning with the previous example in humiliating someone not to get too close because he got elephantiasis disease. 
10. "Nambusok lan tong tungkek men". This kind of utterance may also humiliates that his ear pus stinks bad/ infected.

\subsubsection{Taboo Words Representing Human Body Functions and Parts of Body}

The following terms of taboo words in MPLLBD are associated with something that comes out naturally from human body.

Table 6:

Taboo Words in MPLLBD Representing Human Body Functions.

\begin{tabular}{|l|l|l|}
\hline No. & \multicolumn{1}{|c|}{ MPLLBD } & \multicolumn{1}{c|}{ Glossary } \\
\hline 1. & Bujang & Pussy/Vagina \\
\hline 2. & Bujas & Pussy/Vagina \\
\hline 3. & Cepet & PussyVagina \\
\hline 4. & Bincil & Pussy/Vagina \\
\hline 5. & Kontol & Dick/Penis \\
\hline 6. & Pilat & Dick/Penis \\
\hline 7. & Pukimak & Fuck you! \\
\hline 8. & Tetek & Boobs/Tits/Breast \\
\hline 9. & Muncong & Shut up! \\
\hline 10 & Utak & Jeepers!/Son of a bitch/For God's sake! \\
\hline
\end{tabular}

Bujang, bujas, cepet, bincil (data 1-4), are all the terms of representing to female genitals. While the word "kontol, pilat" are used for male genitals. Those words including the word "pukimak" (data 7) to curse or to abuse someone. Likewise, the word "tetek" uttered is different with the words "muncong" and "utak". Both, in mad situation would sound taboo depending on the context.

Example:

a. "Diam muncong men" (Shut up!!; Taboo/mad)

b. "Kamana utakmu kau bikin!"(Idiots!, Bastard!; Taboo/mad)

\subsubsection{Taboo Words Representing Religion/Faith}

Tabel 7:

Taboo Words in MPLLBD Representing Religion/Faith

\begin{tabular}{|r|l|l|}
\hline No. & \multicolumn{1}{|c|}{ MPLLBD } & \multicolumn{1}{c|}{ Glossary } \\
\hline 1. & Murtad & Apostate \\
\hline 2. & Setan & Setan \\
\hline 3. & Hantu & Ghost \\
\hline 4. & Iblis & Devil \\
\hline 5. & Puaka & A black magic \\
\hline
\end{tabular}

\subsubsection{Taboo Words Representing Animals/Beast}

Tabel 8:

Taboo Words in MPLLBD Representing Animals

\begin{tabular}{|c|l|l|}
\hline No. & \multicolumn{1}{|c|}{ MPLLBD } & \multicolumn{1}{c|}{ Glossary } \\
\hline 1. & Babi & Pig \\
\hline 2. & Lombu & Ox/Cattle \\
\hline
\end{tabular}




\begin{tabular}{|l|l|l|}
\hline 3. & HaRimo & Tiger \\
\hline 4. & ulaR & Snake \\
\hline 5. & Buaya & Crocodile/Alligator \\
\hline 6. & Anjii & Dog \\
\hline 7. & Binatan & Beast \\
\hline 8. & Monyet & Monkey \\
\hline 9. & baRulat & Worm-eaten \\
\hline 10. & Bakapang & Moldy \\
\hline
\end{tabular}

From the table shown above, those words might denote either taboo words or not depending on the context.

The word "pig" is taboo in MPLLBD. However, the animal is illegitimare, forbiddenly eaten and touched based on Moslem's belief. This kind of animal with a long mouth, thickskinned, wire-haired is wicked and interpreted as greedy, grasping, and rapacious. Thus, in MPLLBD the animal is forbidden to eat for health and prohibitedly spoken.

Similarly, words "lombu, haRimo, ulaR, buaya. Anjing, binatang, monyet, baRulat, bakapang". Those might be both taboo or not. See these following sentences.

1. "Babi" (pig). "Bibit kelapa itu dimakan oleh babi".

The word "babi" in the statement above is not considered as a taboo word but not in spoken form. Moreover, if it is spoken by the speaker of MPLLBD in anger, it becomes taboo. Consider the following sentences.

"Pakhakalanmu gaya babi kutengok". This means a rough word to hear where it is uttered such as "Tingkah lakumu, sikapmu, akhlakmu seperti babi". It indicates for someone who acts like a pig.

2. "Lombu" (Ox/cattle)

- "Gaya lombu kutengok ko, asek ondak makan sajo koRjamu".(T). It may refer to the acts of an ox.

- "Bapaknya padagang lombu". (NT). This utterance means his dad is a shepherd.

NB: $T=$ Taboo; NT= Not Taboo.

Lombu (ox/cattle) is an animal that represent a character in every time, chewing, and eating much. Therefore, if a mother i.e gets angry with her indolent child, and does not want to do anything instructed, so the mother would say "Gaya lombu kutengok ko, asek ondak makan sijo koRjamu". (T)

3. "HaRimo (tiger) is a wild animal. (NT)

"Rajokinnya, Rajoki haRimo-haRimoan" (To say: "Sometimes, he is lucky and sometimes he is not").

The word haRimo turns into a taboo word if someone says it in the middle of woods.According to people in Labuhan Bilik, they should not say the word "harimau". It is prohibited, as if tiger would come out. Therefore, the word "datuk" is used to replace it likewise saying the words "snake and alligator".

4. "Ular" (snake). Similarly, the words"haRimo" and "ulaR" are also considered as taboo words at the same context.

5. The word "alligator/crocodile" actually shows the predator but in this case, to indicate a man who loves cheating on many girls and would be called as "buaya darat" representing "playboy" exceedingly it is spoken in anger and means taboo i.e. "DasaR la kobuaya daRat". 6. "Anjing" (dog). It used to indicate someone as if a dog in mad situation. Anjing ko. 
7. 'Binatang" (beast). It might be either taboo and not taboo depending on the contexts as well as the previous examples.

Examples :

"Memang gaya anjing kutengok paRakalanmu en". It means your act is as if as a dog.

8. "Monyet", it has the similar meaning with the example of number 6 and 7 just to humiliate someone mad situation.

9. barulat, (worm-eaten). It indicates to humiliate a person i.e. "Barulat muncong ko" which means a bullshit and to curse.

10. Bakapang, it may have the similar meaning with the words "barulat" to curse someone too such as "bakapang badan ko di siten".

\subsubsection{Taboo Words in Cursing}

This kind of taboo words is actually frightening at Labuhan Bilik because in this area, there is place called as Sikantan Island. Legend told that Si Kantan was a rebellious child and cursed because he disowned his beloved mother. Thus, he was finally condemned and drowned in Berumun river. That happening was known as the legend of Sikantan Island.

Taboo words also represent curse. See these examples:

Tabel 9:

Taboo Words in MPLLBD Representing Curse

\begin{tabular}{|c|l|l|}
\hline No. & \multicolumn{1}{|c|}{ MPLLBD } & \multicolumn{1}{c|}{ Glossary } \\
\hline 1. & Mampus & Damn/Damned you! \\
\hline 2. & Anak haRam Zadah & Illegitimate child/son of a bitch \\
\hline 3. & Hambus & Get away/Begone!/Scram! \\
\hline 4. & muntadaRah & Fall to!! \\
\hline 5. & Honjat & Fall to!! \\
\hline 6. & Hincop & Take it! (rude/impolite) \\
\hline 7. & Cokek & Holy shit! (rude) \\
\hline
\end{tabular}

1. "Lobih elok jako mampus daRipada hidup. Hidup pun ko indak ada gunanya". This utterance refers to: you would better die,there is nothing you can do to live. "mampus" is very taboo to hear not only in MPLLB but also in Indonesian language.

2. "Memang dasaR anak haRam Zahadah". "Indak paguna". When someone says the sentence, it indicates curse to other. Some people do not like the way of expression this because it may hurts somebody.

3. "Hambusko daRi Rumahka". The word "hambus" means to instruct someone getting away or begone.

4. "MuntadaRahlah sasukamu". In this case, the word "muntadaRah" means to curse someone in saying "fall to!".

5. "Honjatlah diko". It has a similar meaning with the word "muntadaRah" in cursing.

6. "Hincoplah nyawanyen ya Tuhan". While this utterance might indicate to ask someone in angry situation which means "take it" (rude or impolite).

7. "Cokeklah diko". It means "Holy shit",

\subsubsection{Taboo Words for Calling People's Names}

The most prohibited words in taboo words are calling parents' names eventhough there is no intention to mock, humiliate, or insult but still it offends the child to hear. The most 
common taboo words used in this part are mentioning the names of mother, father, grandmother, and grandfather where those are stated as impolite way in communication.

\section{Conclusion}

Based on the findings above, the conclusions can be drawn that in MPLLBD, there were some explicit and implicit taboo words. Implicit taboo words mean taboo, abstinence, or prohibited without considering the context. While the explicit taboo words represent the use of taboo words in contextual meaning depending on the way of using and the situation needed.

There were some classifications of taboo words in MPLLBD, associated with the contexts of sex, death, excretion, parts of human body, religion, animals, curses, and names.

\section{References}

Hakim. M. L. (2013). Tabu dalam Masyarakat Gorontalo: Taboo among Gorontalonese in Gorontalo Province. Academia Edu. Retrieved 10 1 th January 2019 from https://www.academia.edu/9578082/tabu dalam masyarakat Gorontalo

Jay, T. (1999). Why We Curse. Philadelphia, PA, USA: John Benyamin Publishing Company. $\begin{array}{lllll}\text { Accessed } & \text { on } 11^{\text {th }} & \text { January } & 2019 & \text { (pp.25). }\end{array}$ http://site.ebrary.com.ezproxy.bibl.khr.se/lib/kristianstad/Top?/layout=document\& $\mathrm{id}=5000152 \& /$ nosr $=1>$

Jay, T. (2009). The Utility and Ubiquity of Taboo Words. Psychological Perspective on Science. 4(2). Retrieved $11^{\text {th }}$ January 2019 from https://pdfs. semanticscholar.org/ce08/eaf2cef490b8fed91e66b173bdf34fb2386c.pdf.

McGuire, W. J. (1973). The Yin and Yang of Progress in Social Psychological Research. In Advances Experimental Social Psychology, ed. L. Berkowitz, 16:1-47. New York: Academic.

Moleong, L. J. (2012). Metodologi Penelitian Kualitatif. Bandung: PT. Remaja Rosdakarya.

Trudgill, P. (2000). Sociolinguistics: An Introduction to Language and Society. (4 ${ }^{\text {th }}$ ed.). England: Penguin.

Wardhaugh, R. (2006). An Introduction to Sociolinguistics. (6 $6^{\text {th }}$ ed.). Australia: Blackwell. 